\title{
Urban Heat Island (UHI) Mitigating Strategies: A Case-based Comparative
}

\author{
Analysis
}

\author{
Mr. Christopher O'Malley, MSc \\ Ground Construction Ltd. One Oaks Court, Warwick Road, Borehamwood, Herts, WD6 1GS, UK \\ Dr. Poorang Piroozfar, PhD
}

School of Environment and Technology, University of Brighton, Cockcroft Building, Brighton, East Sussex, BN2

4GJ,UK (Corresponding Author; Email: A.E.Piroozfar@Brighton.ac.uk)

Dr. Eric R. P Farr, PhD

NewSchool of Architecture and Design, 1249 F Street, San Diego, CA 92101, USA

Mr. Francesco Pomponi, MSc

School of Environment and Technology, University of Brighton, Cockcroft Building, Brighton, East Sussex, BN2 $4 G J, U K$

\begin{abstract}
Urbanisation may have been shown to have no effect on climate change, but some researchers suggest that cities are fully capable of responding to it. Urban Heat Islands (UHIs) represent dense urban areas within cities where the temperature is recorded to be higher than the neighbouring areas or those located in suburbia. Mitigation of UHI effects can help diminish detriments of climate change. This paper sets out to establish UHI mitigation strategies, their effectiveness and resilience to help provide recommendations for application of such strategies in future. Existing literature suggest that UK is facing with growing problem of UHI effects and sustainable development at urban scale can be improved if proportionate measures are taken to mitigate those effects. The lack of guidance for designers and planners with regards to UHI mitigation is also indicated in the literature where trees, shrubs and grass (TSG), use of high albedo materials (HAM) in external building surfaces and urban inland water bodies (UIWB) are identified as effective measures to mitigate UHI. This research identifies and tests resilience and effectiveness of UHI mitigation strategies, using ENVI-met simulations and through Urban Futures Assessment Method (UFAM). Assessed mitigation strategies (TSG, HAM, UIWB) are shown to have a similar level of resilience which could be improved if proper future-proof measures are taken in place. As a result, some practical suggestions are provided to help improve the resilience of tested UHI mitigation strategies in this study.
\end{abstract}

Keywords: Mitigating Strategies; Sustainable Cities; Urban Heat Island Effect; Urban Resilience; Urban Sustainability. 


\section{Introduction}

Cities accommodate over $50 \%$ of the world's population (Jansson, 2013). While some may have suggested that urbanisation has limited to no effect with respect to climate change (Parker, 2004; Peterson, 2003), some others indicate that cities are effectively capable of responding to it (Emmanuel \& Krüger, 2012; Hoornweg et al., 2010; Moss, 2009). Nevertheless, cities now contribute to $60 \%-85 \%$ of the world's energy consumption (Kamal-Chaoui \& Roberts, 2009; Nakicenovic \& Swart, 2000) and it is not credulous to expect that concentration of energy consemption activities on an over-crowded highdensity area of land, have an impact on at least local, if not global, warming. This is due to the need for heating and cooling the indoor spaces, and hot water in buildings and in some cases due to presence of fuel intensive industries (UN, 2010). Therefore, ideas about how to effectively combine urbanisation and sustainability are of critical and immediate importance (Kamal-Chaoui \& Roberts, 2009).

This research aims to investigate mitigation strategies for Urban Heat Island (UHI) phenomenon to gauge resilience and promote urban sustainability. Resilience in this paper refers to the extent to which these $\mathrm{UHI}$ mitigation strategies will be able to achieve their design purpose and sustain in the face of a changing future. Urban Futures Assessment Method (UFAM) will be employed to assess the resilience of UHI mitigation strategies. ENVImet will be deployed to simulate UHI effects in the selected case for this study, a planned development in borough of West Kensington in London (Figure 1).
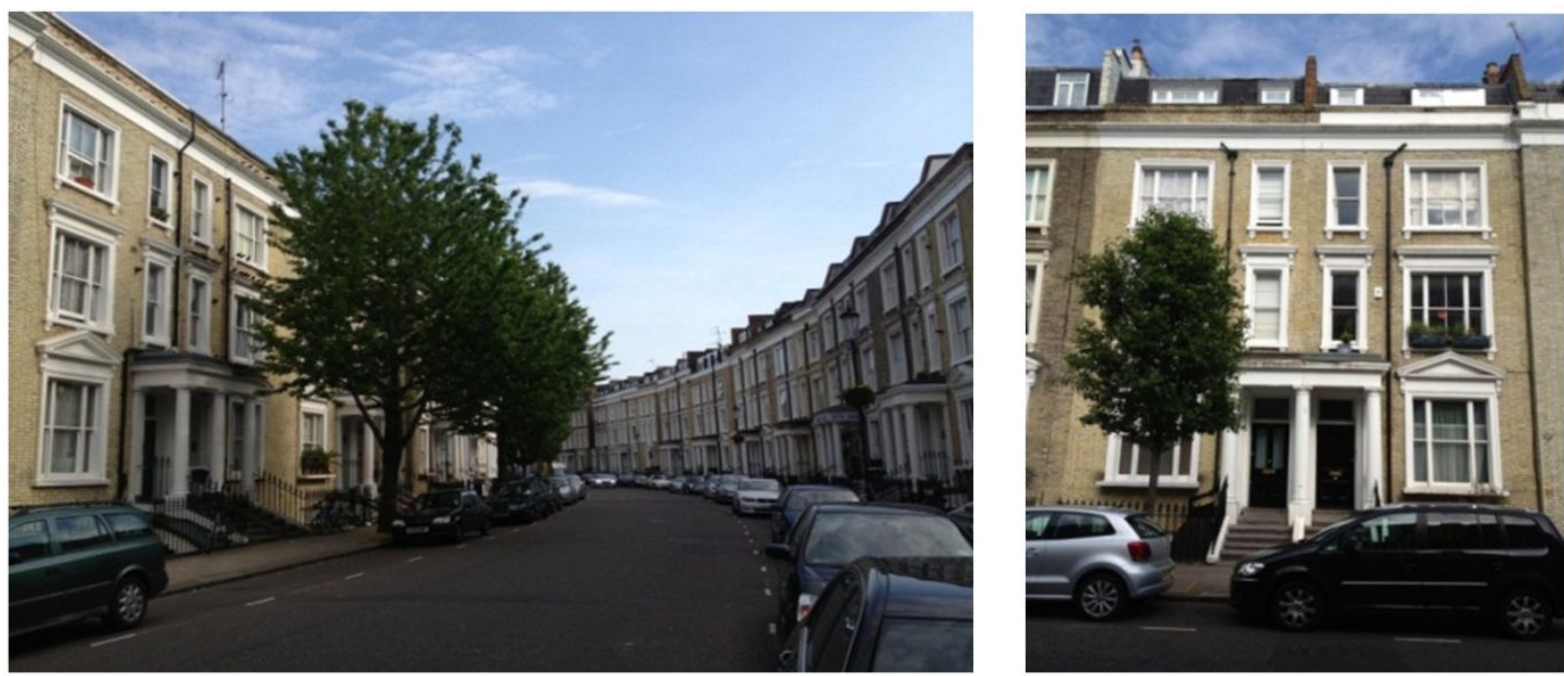

Figure 1 - West Kensington, London 
The research is expected to be used first and foremost as a methodology for similar interventions and subsequently as a frame of reference for more sustainability-informed decisions for interventions at planning, design, implementation and operation phases for different experts including architects, urban designers, urban planners and city authorities.

\section{Review of existing literature}

\subsection{Sustainable city}

Cities offer great opportunities to eliminate the detriments of climate change. They have an indispensable role in leading towards, and securing of a sustainable future for humankind (Alusi et al., 2011; Folke et al., 2011; Jansson, 2013; Mitchell, 2009; Moss, 2009; Rosenzweig et al., 2009). A sustainable city can be defined as a multifaceted complex entity with numerous interconnected networks and cycles (Mitchell, 2009). Recently the concept of sustainability has been intertwined closely with the notion of resilience as the latter is seen as inevitable if the former is intended to cling to a more sustained future. Resilience of cities and the need for cities of the future to be resilient has been identified as a necessary measure for the city of future and described as a response to environmental disturbance, how habitats and ecosystems can re-organise spontaneously after a disturbance, or as vulnerability of a system to irreversible change (Dieleman, 2013; Jabareen, 2013; Jansson, 2013; Muller, 2007). Today's sustainable strategies are expected to maintain the capability to deliver their intended benefits whatever the future may hold (Lombardi et al., 2012).

\subsection{The urban heat island (UHI)}

The UHI is a phenomenon where a significant difference in temperature can be observed within a city or between a city and its suburbia and/or its surrounding rural areas (Kolokotroni \& Giridharan, 2008) and areas of maximum temperature can expectedly be found within the densest part of the urban area (Giannopoulou et al., 2011). Despite the common understanding, recent studies suggest that UHI can be found even in medium-tosmall size cities (Busato et al., 2014). In fact some studies suggest that the impact of UHI effects may be even higher on smaller cities. A specific case indicates a UHI peak of $6^{\circ} \mathrm{C}$ for a city of just over 200,000 people while significantly bigger cities with more than a million inhabitants have peaked at just above $2^{\circ} \mathrm{C}$ (Borbora \& Das, 2014). Such evidence suggests 
that the UHI phenomenon could be much more common than it is currently believed to be. $\mathrm{UHI}$ is commonly illustrated in Figure 5.

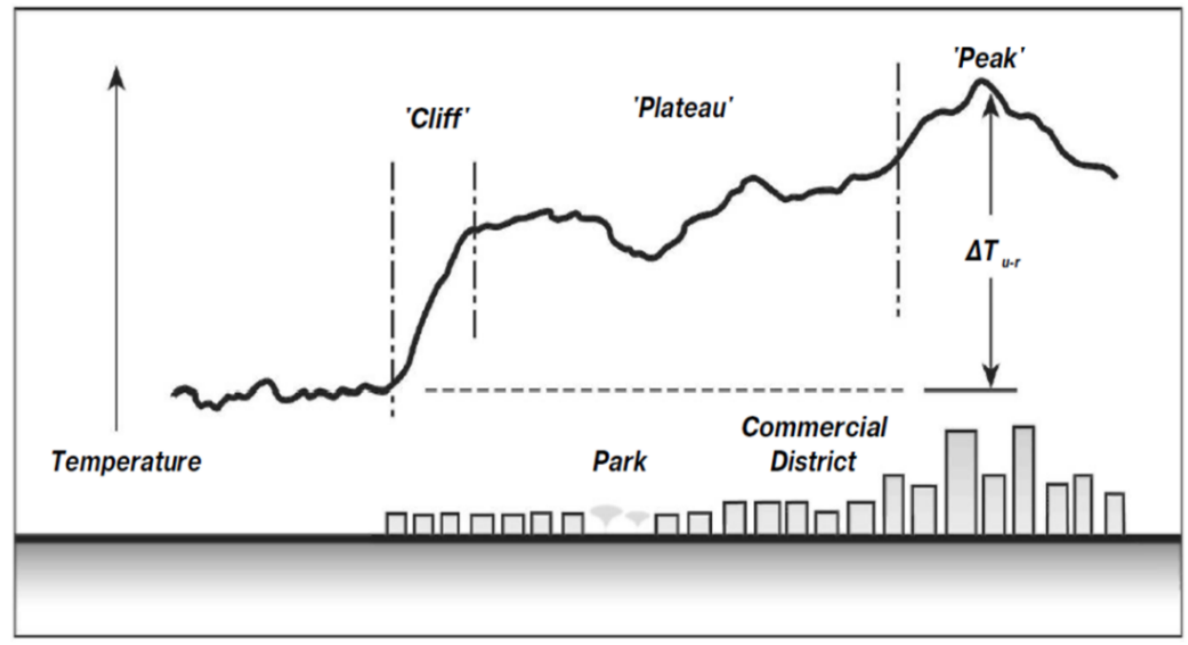

Figure 5 - UHI effects in city districts and its suburbia [19]

\subsection{Causes and effects}

Anthropogenic heat emissions, pollution and energy consumption within a city (Santamouris et al., 2011), intensive land use and high density in urban areas combined with buildings with high thermal masses and heat retaining properties (Harlan \& Ruddell, 2011; Mavrogianni et al., 2011), urban street canyons effects resulting in lower rates of long-wave radiation loss during the night (Santamouris et al., 2011; Smith \& Levermore, 2008), reduced speed of wind caused by design and layout of the built environment (Santamouris et al., 2001), lack of green areas and presence of materials with reduced permeability (H. Chen et al., 2009; Smith \& Levermore, 2008), and presence of low-albedo materials on buildings external façades and road surfaces (Santamouris et al., 2011) are known to be the most significant causes of UHI.

UHI effects can be classified under two broad categories: people and (micro)climates. However, the two are not mutually exclusive. The deterioration of physical well-being of a city's population (Fujibe, 2011 among others), thermoregulatory system damage induced by heat stress in the form of heat syncope, cardiovascular stress, thermal exhaustion, heat stroke and cardiorespiratory diseases (Kleerekoper et al., 2012; Rydin et al., 2012) are the ones with adversarial effects on inhabitants of a city which incur some secondary effects on microclimate by trying to improve the indoor comfort conditions 
within individual buildings. On the other hand elevated air temperature has a negative effect on the microclimates within cities compared to rural areas (Erell et al., 2011; Hathway \& Sharples, 2012; Wilby, 2003), by formation of ground level ozone (Kleerekoper et al., 2012), alteration of local micro- and macro-climates i.e. wind patterns, humidity changes, storms, floods, and change in local ecosystems (Lee, 1991; Mikami, 2005; Sailor \& Fan, 2002) and lastly exacerbation of global warming by increased energy consumption for airconditioning and increased heat emissions released into the local environment (Kolokotroni et al., 2012). To the contrary urban gardens are known to provide a suitable solution to improve the quality of life, energy poverty, urban heat stress and biodiversity in the urban environment (Tsilini et al., 2015). Each of these effects pertaining to climate bears a secondary implication and in most cases a resonating drift on other effects directly involving the city's inhabitants.

\subsection{Assessment methodologies and mitigation strategies}

Prediction methodologies (such as artificial neural network) have been used to help predict peak energy loads during heat waves and hot summer days to manage supply and demand (Gobakis et al., 2011). Studies have used different tools and techniques including in-situ measurement and monitoring (Borbora \& Das, 2014; Busato et al., 2014), CFD simulaition in combination with in-situ measurement (Dimoudi et al., 2014; Georgakis et al., 2014), and artificial neural network either in combination or independent from fuzzy logic (Gobakis et al., 2011; Mihalakakou et al., 2002; Santamouris et al., 1999), simulation (Tsilini et al., 2015) to assist measuring, evaluating and prediction of the magnitude and effects of UHI.

Regardless of the tools and techniques used for specific cases, major assessment methods such as Leadership in Energy and Environmental Design (LEED), Building Research Establishment Environmental Assessment Methodology (BREEAM), Comprehensive Assessment System for Built Environment Efficiency (CASBEE) and Building Environmental Assessment Method (BEAM) include criteria for mitigation of UHI effects. CASBEE provides the most comprehensive account of UHI parameters, spreading across its three toolkits: CASBEE for Home (Detached Houses), CASBEE for New Construction, CASBEE for Urban Development. UHI mitigation is not covered in BEAM as extensively as it is in CASBEE, but the criteria which BEAM represents for $\mathrm{UHI}$ mitigation are very similar to CASBEE. UHI 
mitigation measures are not detailed in LEED to the same extents as CASBEE or BEAM but where they are, similarities are evident. Taking a slightly different approach the Building Research Establishment (BRE) introduces BREEAM Communities which has assessment criteria to improve the urban microclimates. Although those criteria are not directly labelled as UHI mitigation measures, they can be associated with UHI effects since they aim to improve the health and well-being by offering the benefits of mitigation of UHI effects. These are capable of informing and, in the most optimistic scenarios, influencing the UHI mitigation strategies indirectly. As a result, a general consensus in assessment parameters across all the methods can be summarised as: ventilation or passage of air, shading of buildings, presence of green areas or roofs, use of water and, external use of high albedo materials on buildings' surfaces.

The inclusion of water retentive or porous materials in the design of the built environment, for example green roofs or porous paving has been pointed out in some previous research (Hathway \& Sharples, 2012). High albedo materials in building design and shading of urban areas by trees or man-made structures (Takebayashi \& Moriyama, 2012), cool materials for street and pavement covers (Dimoudi et al., 2014), green spaces at city scale such as parks and open fields (Rydin et al., 2012; Santamouris, 2014), presence of urban water bodies such as rivers and lakes within a city (Kleerekoper et al., 2012), and harnessing natural wind (Smith \& Levermore, 2008) are other measures or strategies to mitigate UHI effects. However, "to appropriately select a UHI measures technology, the relationship between the environment where the technology has been introduced and the effect of introducing this technology must be studied" (Takebayashi et al., 2014, p. 217). In the next section the specific approach of this study will be explained. 


\section{Methodology}

The existing literature was critically reviewed with an aim to investigate the concept of UHI in general and more specifically in correlation with the concept of sustainability and resilience at city scale. The review was also deployed to further investigate causes, effects and mitigation strategies of UHI. Next, current measures used in environmental assessment methods to mitigate (or at least denote) UHI were also reviewed, compared and analysed across the globe. Subsequently three UHI mitigation strategies were selected for further assessment. A combination of qualitative and quantitative methods was selected as this would yield uniform basis throughout the intended outcomes while providing multiple avenues of discussion. The first selected

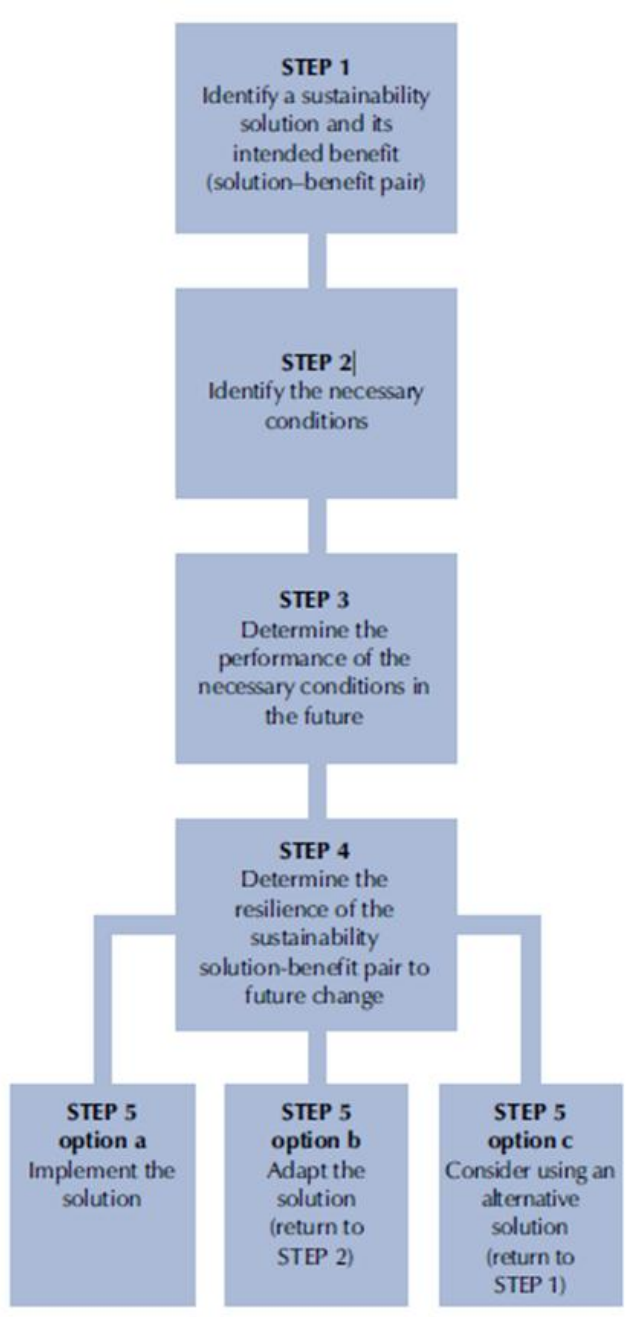

assessment methodology was the Urban

Figure 2 - UFAM Step Process (Lombardi et al., 2012)

Futures Assessment Method (UFAM) which

assesses the resilience of the selected mitigation strategies. The UFAM is a 5-stage assessment methodology (Figure 2) which assesses the ability of today's sustainable strategies to deliver their intended benefits in the future.

The success of a sustainable strategy depends on its level of performance in four possible future scenarios set for the year 2050. At next stage a selected sampling method was adopted to find appropriate participants for interviews to further investigate the assessment methodology and address possible areas of improvement for practical application of this methodology from an expert's point of view. The interviewees consist of individuals in the Urban Futures team, urban designers/planners who work in London and project team for Earl's Court and West Kensington Opportunity Area developments where 
Seagrave site (Figure 3), the witness test case for the selection of suitable methodologies, is located.

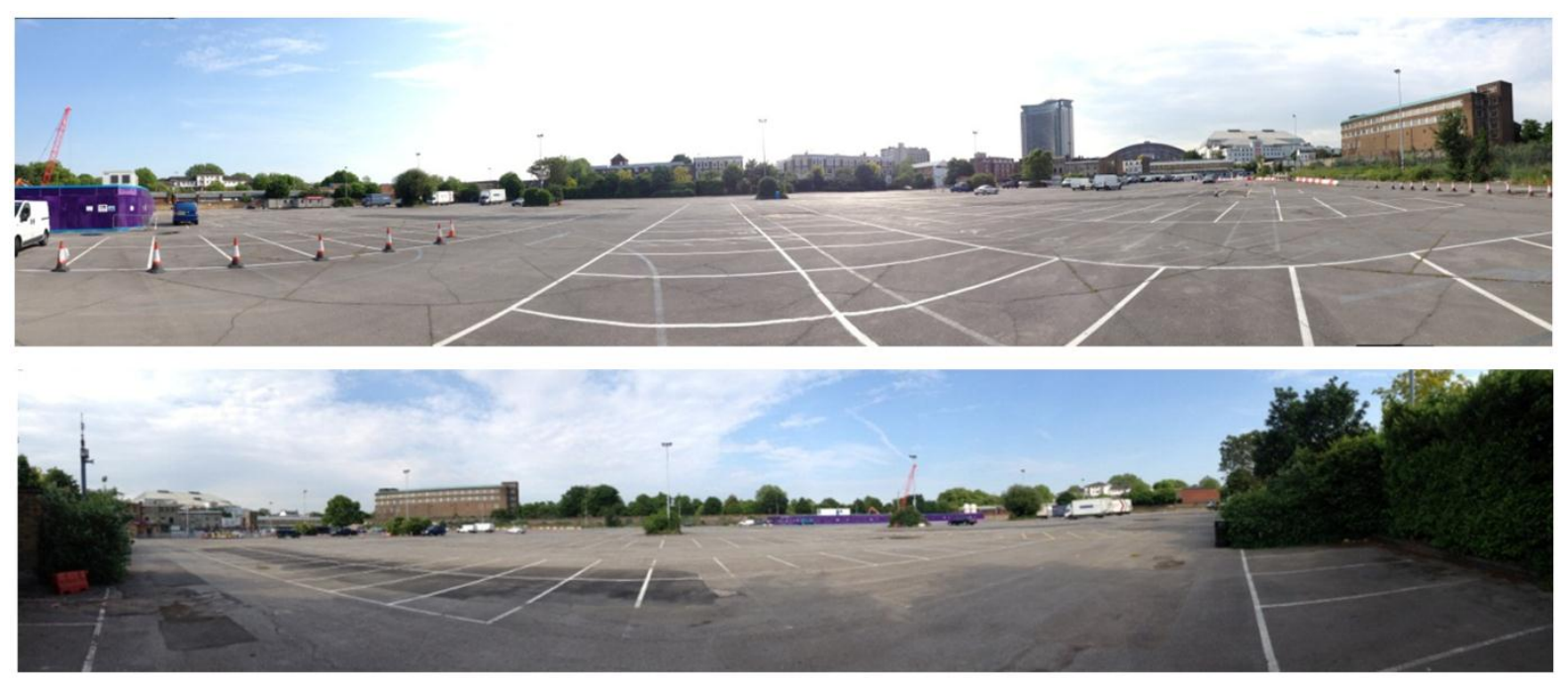

Figure 3 - Seagrave site for planned development

The initial list included 50 recipients, which was narrowed down, in two different stages using purposeful sampling techniques, to 7 in order to have representation from all the expert groups included yet to avoid excessive data. Part of the proposed guidelines will be based upon numerical data demonstrating the efficacy of each UHI mitigation strategy.

Figure 4 shows the proposed scheme for the Seagrave site: 


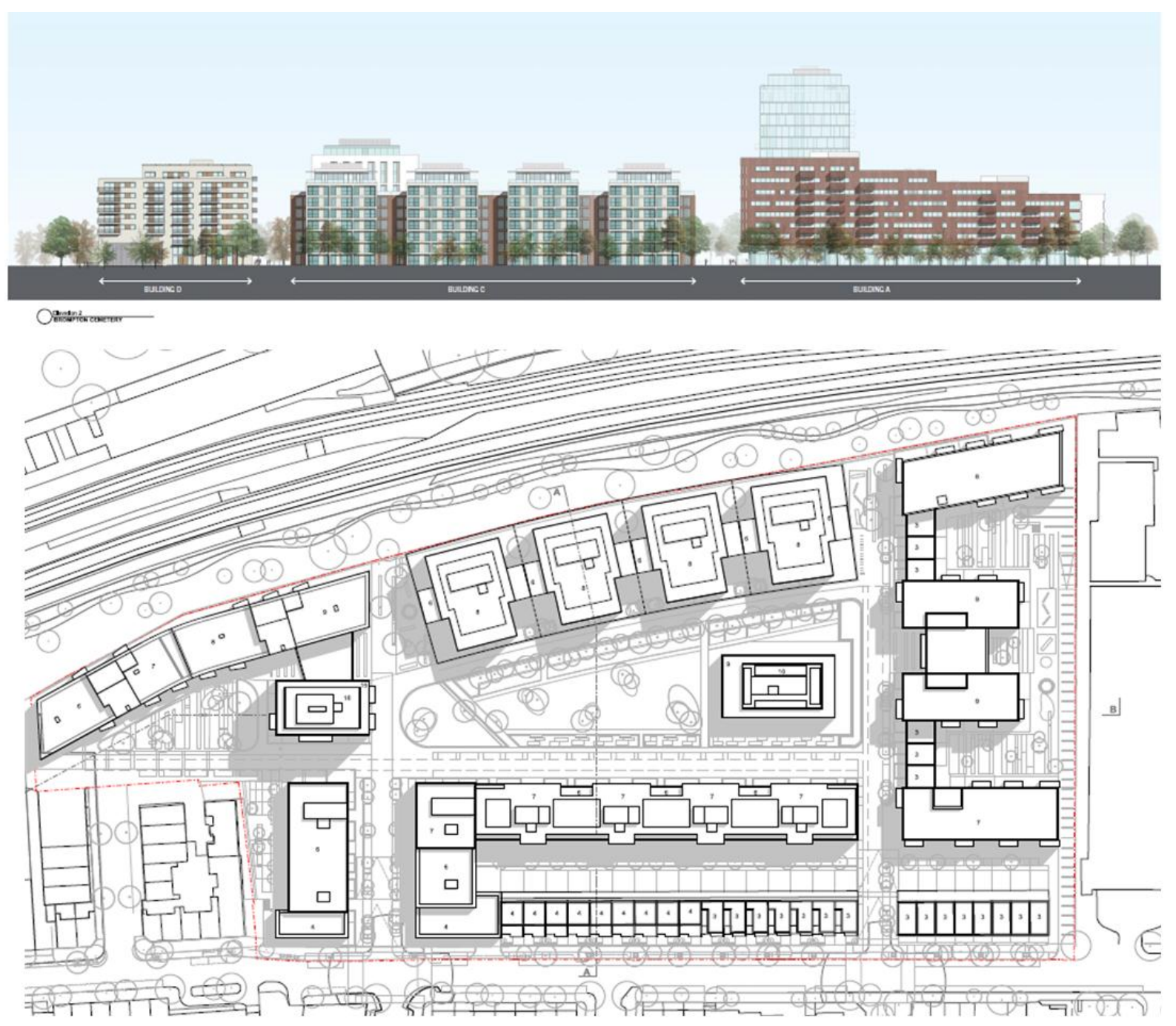

Figure 4 - Seagrave Development: East Elevation (above) and Site Plan (below)

\subsection{Tool}

The efficacy of each UHI mitigation strategy will be determined based upon simulations conducted by ENVI-met simulation software which has already been used successfully in UHI studies (e.g. Chow et al., 2011; Lahme \& Bruse, 2003; Tsilini et al., 2015). Results from UFAM and ENVI-met assessment were then used to provide guidelines for urban planners aiming at mitigation of UHI effects. This has been achieved through triangulation of outcomes interpreted and drawn out from the literature review, expert interviews and the simulations. Furthermore, ideas which were developed in post data analysis stages were also used to inform conclusions and suggestions for further research.

ENVI-met is a three-dimensional non-hydrostatic microclimatic model that allows for complex modelling and detailed investigation of urban microclimate. It shows a good resolution that satisfactorily models small-scale interactions between buildings, surfaces, 
and plants (Emmanuel et al., 2007). More specifically, ENVI-met has been proven capable of suitably simulating "major processes in the atmosphere that affect micro-climate" based on a well-grounded "physical basis (i.e. the fundamental laws of fluid dynamics and thermodynamics)..." (Ali-Toudert \& Mayer, 2006, p. 96). In a comparative review of existing tools to assess physical parameters of urban microclimate, Moonen et al. (2012) acknowledge ENVI-met as a suitable tool for complex models, which takes into account a broad spectrum of relevant and determinant factors. With specific reference to the assessment of UHI mitigation strategies, Emmanuel et al. (2007) have selected ENVI-met as the most suitable model for analysing thermal comfort regime within the street canyon and urban canopy layer at fine resolutions. $\mathrm{Ng}$ et al. (2012) proved reasonable agreement between field measurement and ENVI-met simulations. A successful deployment of ENVImet can also be found in Roset Calzada and Vidmar (2013), Jesionek and Bruse (2003), Bruse (2009), and Ozkeresteci et al. (2003), just to name a few. Positive confirmations of ENVI-met capability to simulate temperature also come from Jänicke et al. (2015) and (Chen et al., 2014). However, both studies also highlighted some shortcomings as far as long- and shortwave radiations are involved.

Notwithstanding ENVI-met suitability to approach the study of UHI mitigation strategies, like every other modelling and simulation tool, it also has its intrinsic limitations rooted in an attempt to simplify and ostensibly represent a far more complex reality. In the specific case of ENVI-met, the main weaknesses relate to: 1 ) the capability of establishing relative quantities such as absolute temperature profiles and air temperature throughout the diurnal cycle (Carnielo \& Zinzi, 2013; Hedquist et al., 2009; Spangenberg et al., 2008) and wind speeds (Krüger et al., 2011); 2) the inability to dynamically simulate heat storage for building walls and roofs because of constant building indoor temperatures (Chow \& Brazel, 2012; Chow et al., 2011; Fahmy et al., 2011); 3) the simplification of building façades to a single, averaged heat transfer coefficient (Chow \& Brazel, 2012; Spangenberg et al., 2008); 4) the lack of horizontal soil transfer within the model that potentially affects accurate calculations of soil heat storage (Chow \& Brazel, 2012); and, 5) difficulties regarding interpreting pollutant dispersal results (Krüger et al., 2011). 


\subsection{Selected mitigation strategies}

Mitigation strategies which have been selected for evaluation within this research project are as follows:

- Vegetation in the form of trees, shrubs and grass (TSG) (Figure 6);

- Presence of water in form of urban inland water bodies (UIWB) - excluding rivers and waterways (Figure 7);

- Use of materials with high albedo rating (HAM).

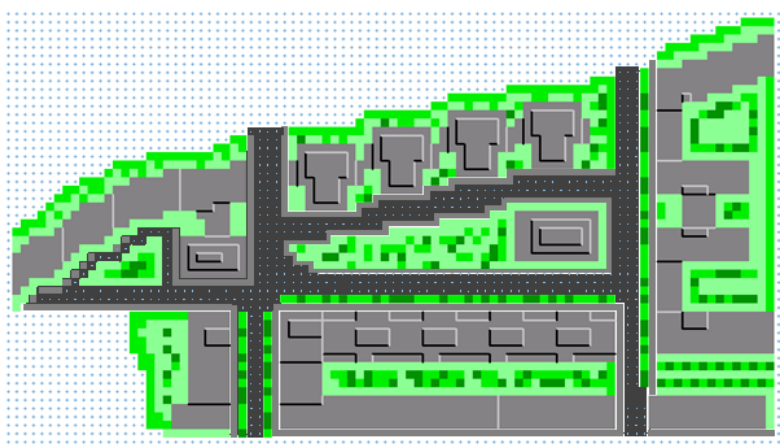

Figure 6 - Area Input file for TSG

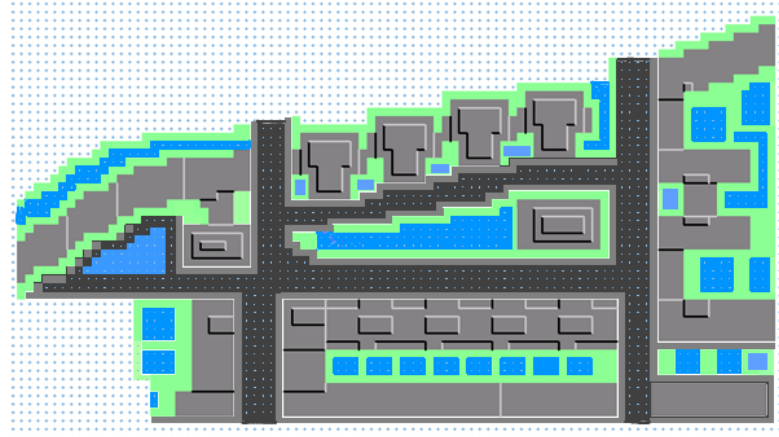

Figure 7 - Area Input file for UIWB

In addition to the findings through critical review of literature in support of the selected strategies, other empirical reasons for this selection justify the choice of the selected strategies. First and foremost, the selected strategies are among the most commonly design solutions preferred by urban planners, architects and landscape architects. Secondly and more importantly they are favoured by the general public, or at worst they are the least objected solutions by the general public for their limited impact on the plethora of different elements, issues and determinants in urban spaces. And finally they seem to be the most affordable strategies both at the design stage - technically, financially and aesthetically, and also in implementation, operation and maintenance stages which make them appear on top of the priority list of actions for local authorities.

\section{Results}

\subsection{Benchmark}

Figure 8 (top) demonstrates the comparison between the four receptors temperature $2 \mathrm{~m}$ above ground level in degrees Kelvin and shows that the peak air 
temperature throughout the time simulated has recorded in the 14:00-15:00 hourly time bracket. Furthermore, the graph shows receptors C1, C2 and C3 rising at a similar rate between 9:00 and 15:00 while receptor C2 maintaining the lowest temperatures within this period, followed by $\mathrm{C} 1$ and then $\mathrm{C} 3$. Receptor C4 rises at a higher rate and reaches a significantly higher peak temperature than the other receptors in 14:00-15:00 time bracket.

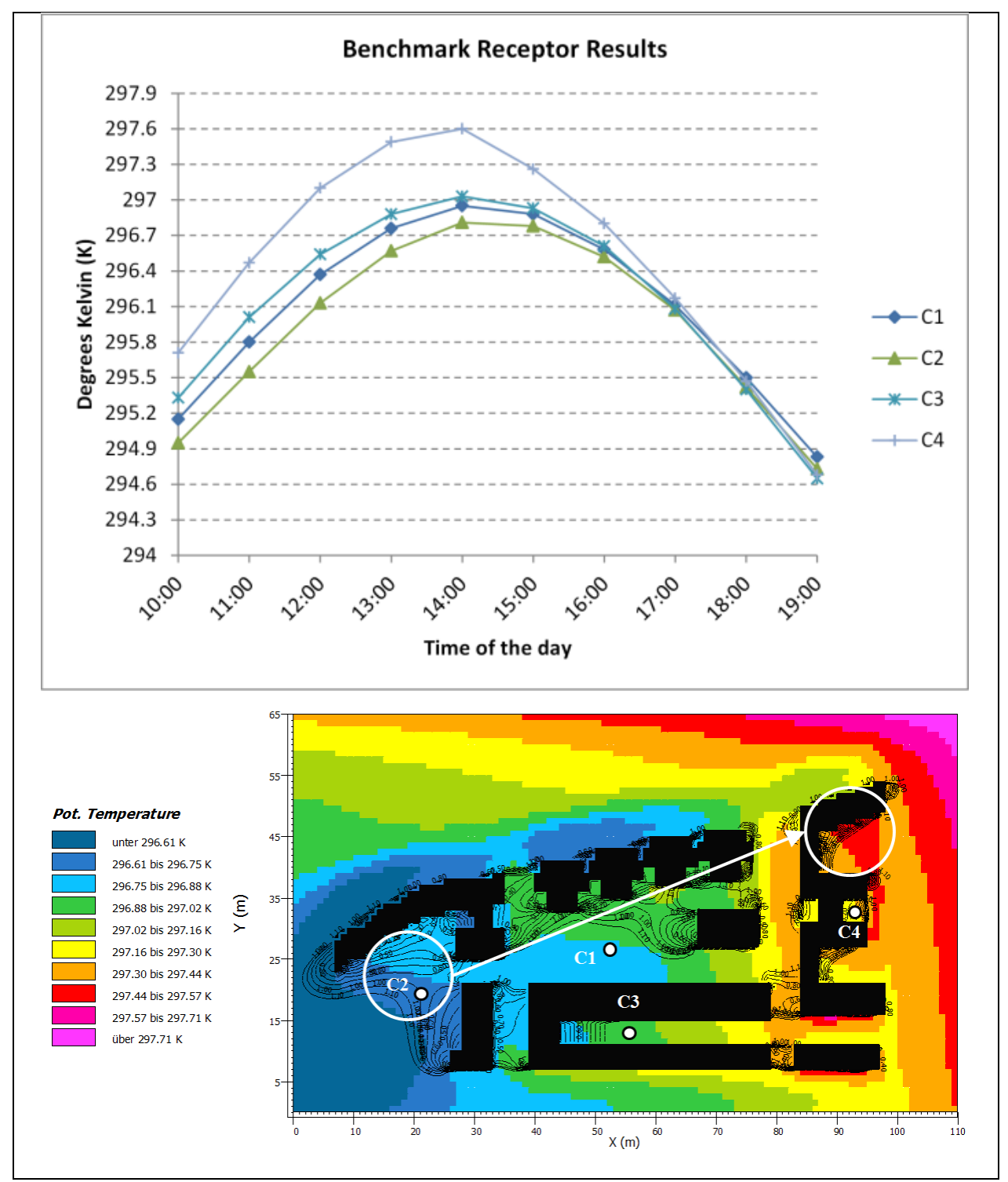

Figure 8 - Benchmark data: temperature at receptors (degrees Kelvin) during the day (top) and, Heat distribution across Seagrave site (bottom)

Between 15:00 and 19:00 receptors C1, C2 and C3 fall at a similar rate and share similar temperatures between 16:00 and 20:00. Receptor C4 falls at a higher rate than other receptors between $14: 00 \mathrm{pm}$ and $17: 00 \mathrm{pm}$ and also shows similar temperatures as other receptors between 17:00 and 19:00. This graph demonstrates that the different parts of the site have consistently different rising temperatures between 9:00am and 15:00pm (C4 rises 
slightly quicker). However when the overall temperature of the site is decreasing in the afternoon the site actually has similar temperature across all areas. Figure 8 (bottom) shows temperature distribution in degrees Kelvin across the site at 14.00 to 15.00 , the hottest time of day, and the location of benchmarks. A general trend can be seen as lower temperatures is observed at the bottom left corner of the graph gradually increasing across the site to top right area where the highest temperature seems to be prevailing. This can be attributed to the shadows of the buildings and also the fact that site landscape escalates the microclimate effects of some areas. It is however, important to note that the temperature difference is around 1.1 degrees Kelvin.

\subsection{Vegetation - Trees, Shrubs and Grass}

Figure 9 (top) presents a comparison between the four receptors temperature in degrees Kelvin up to $2 \mathrm{~m}$ above ground level and shows that the peak air temperature throughout the time simulated is between $14: 00$ and $15: 00 \mathrm{pm}$. The graph shows receptors C1, C2 and C3 rising at a similar rate with similar temperatures between 9:00 and 15:00 with receptor C3 maintaining the lowest temperatures within this period, followed by C2 and then $\mathrm{C} 1$. Receptor C4 again rises at a greater rate and reaches a higher peak temperature than the other receptors between 14:00 and 15:00. Between 15:00 and 19:00 receptors $C 1$, C2 fall at a similar rate and share similar temperatures between 16:00 and 20:00. C3 falls at a higher rate than the other receptors in the afternoon. This may be because of the increased shading as a result of the $5-10 \mathrm{~m}$ dense trees combined with the shadow of the nearby buildings. Receptor C4 falls at a higher rate than other receptors between 14:00 and 17:00 and also shares similar temperatures as C2 and C1 between 17:00 and 19:00. It also demonstrates that receptors $\mathrm{C} 1, \mathrm{C} 2$ and $\mathrm{C} 3$ consistently have similar rising temperatures between 9:00 and 15:00, C4 rises slightly quicker reaching peak site temperature. Between 15.00 and 19.00 C1, C2 and C4 share similar falling temperatures however receptor C3 maintains the lowest temperature throughout the day with this difference increasing between time passes. Figure 9 (bottom) shows temperature distribution in degrees Kelvin across the site for the TSG between 14.00 and 15.00. A general trend can be seen as cooler lower temperatures being present from bottom left corner of the graph gradually increasing across the site to the top right area where the highest temperatures are present. The 
temperature difference is 1.12 degrees Kelvin. Table 1 shows the final parameters inputted into the UF assessment tool and resilient value out of 10 for TSG.

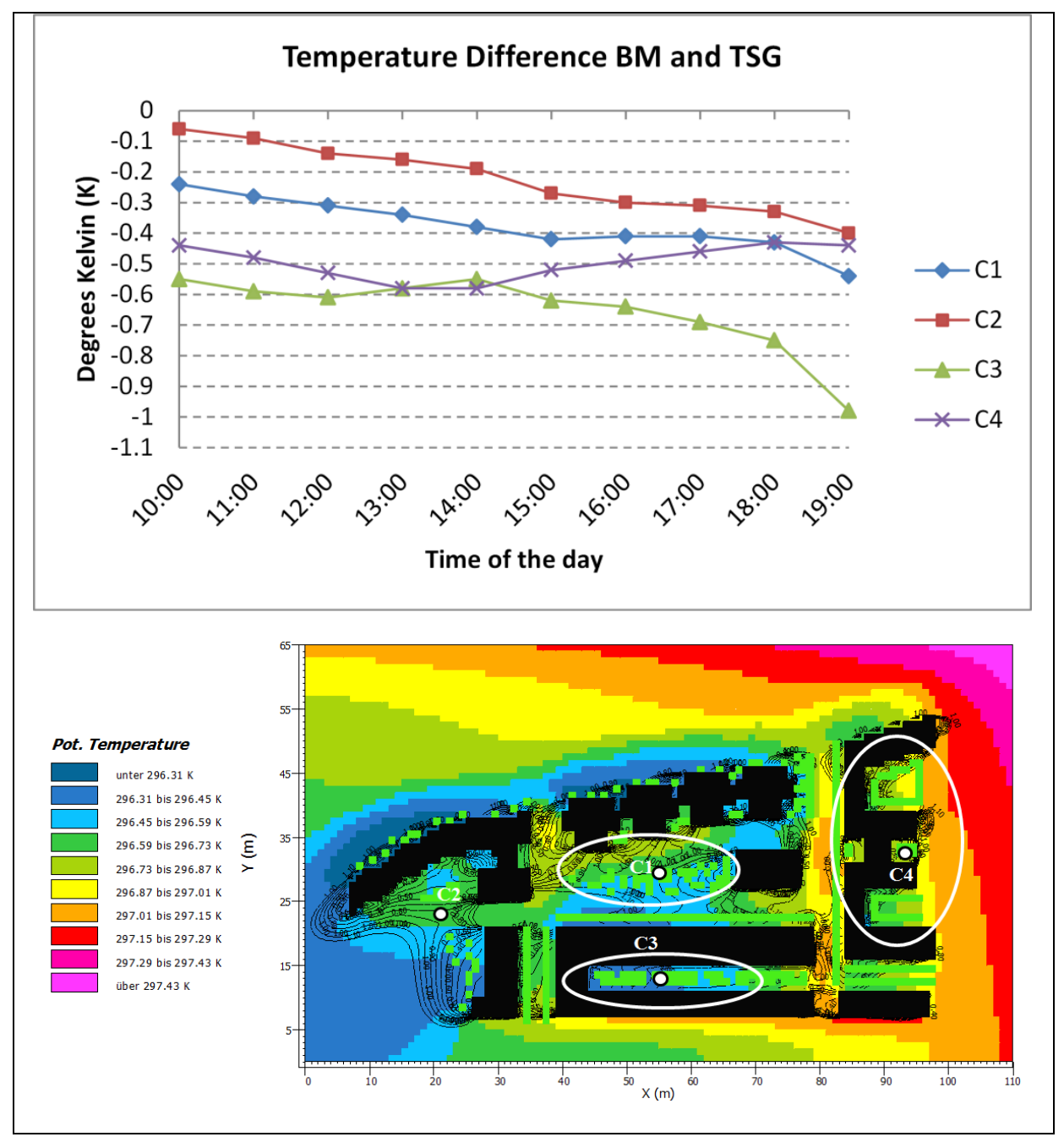

Figure 9 - Trees, Shrubs and Grass data: Temperature at receptors (degrees Kelvin) during the day (top) and, Heat distribution across Seagrave site (bottom)

\begin{tabular}{llc}
\hline \multicolumn{1}{c}{ UHI Mitigation Strategy } & \multicolumn{1}{c}{ Conditions } & Resilient Value \\
\hline $\begin{array}{l}\text { Trees, Shrubs and Grass } \\
\text { (Trees 5-10m high, Shrubs } \\
1.5 \mathrm{~m} \text { max height, and Grass }\end{array}$ & Retained & Maintained \\
$0.1 \mathrm{~m}$ max height) & Correctly located & $\underline{\mathbf{6 . 2 5}}$ \\
\hline & Retained & \\
Urban Inland Water Bodies - & Abundance of Water & $\underline{\mathbf{6 . 6 7}}$ \\
Lakes / Ponds & $\begin{array}{l}\text { Remains exposed to } \\
\text { direct sunlight }\end{array}$ & \\
\hline & Retained & \\
High Albedo Materials & Maintained & $\underline{\mathbf{6 . 2 5}}$ \\
& $\begin{array}{l}\text { Correctly located in } \\
\text { Building Design }\end{array}$ \\
\hline \hline
\end{tabular}

Table $\overline{\overline{1-\text { Parameters inputted into the UF assessment tool and corresponding resilient }}}$ values 


\subsection{Presence of Urban Inland Bodies of Water (excluding waterways and rivers)}

Figure 10 (top) demonstrates the comparison between the four receptors temperature in degrees Kelvin up to $2 \mathrm{~m}$ above ground level and shows that the peak air temperature throughout the time simulated is between 14:00 and 15:00. Again the general trend is similar to the other data sets with temperatures for the four receptors. However for UIWB all four receptors rise at same rate and maintain similar differences in temperature from 15.00 to 20.00 where their temperature differences reduce and they fall at a similar rate. The data presented in the graph indicates that as a general trend the area of the site with the highest temperatures is where receptor $\mathrm{C} 4$ is positioned.

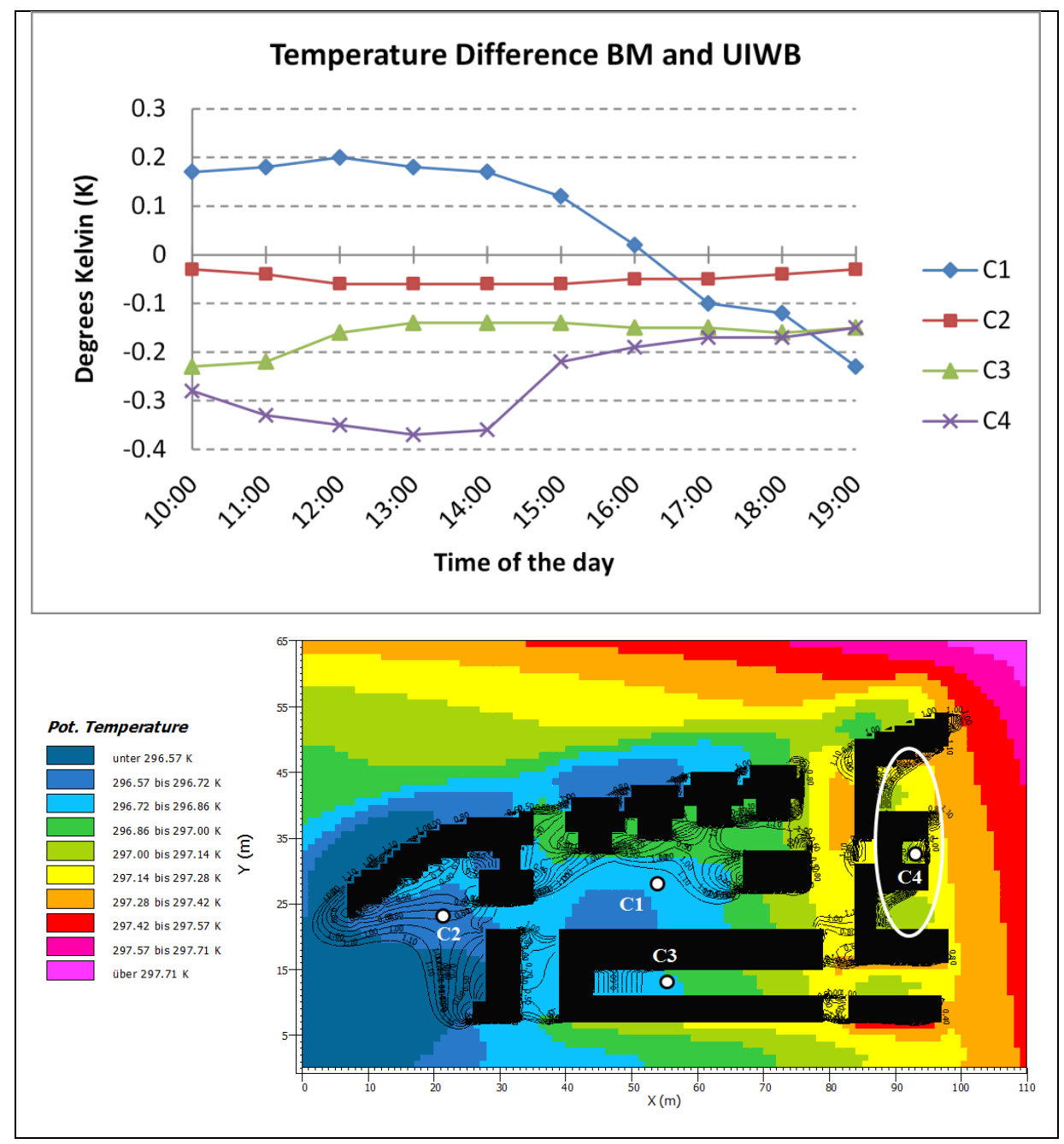

Figure 10 - Urban Inland Bodies of Water data: Temperature at receptors (degrees Kelvin) during the day (top) and, Heat distribution across Seagrave site (bottom)

Figure 10 (bottom) shows temperature distribution in degrees Kelvin across the site for the water data. Again the trend seems to be that of cooler lower temperatures being present at bottom left corner of the graph gradually increasing across the site to top right 
area, showing a difference of 1.14 degrees Kelvin. Table 1 represents the final parameters inputted into the UF assessment tool and resilient value out of 10 for UIWB.

\subsection{High Albedo Materials}

Figure 11 (top) shows a comparison between the four receptors temperature in degrees Kelvin up to $2 \mathrm{~m}$ above ground level. The peak air temperature throughout the time simulated is between 14:00 and 15:00. Previous trends already present in BM, TSG and UIWB are also present for HAM. Except between 9.00 and 15.00 receptor C4 increases in temperature at a greater rate and also reaches a peak temperature which is the highest witnessed anywhere within simulation area for all UHI mitigation strategies.

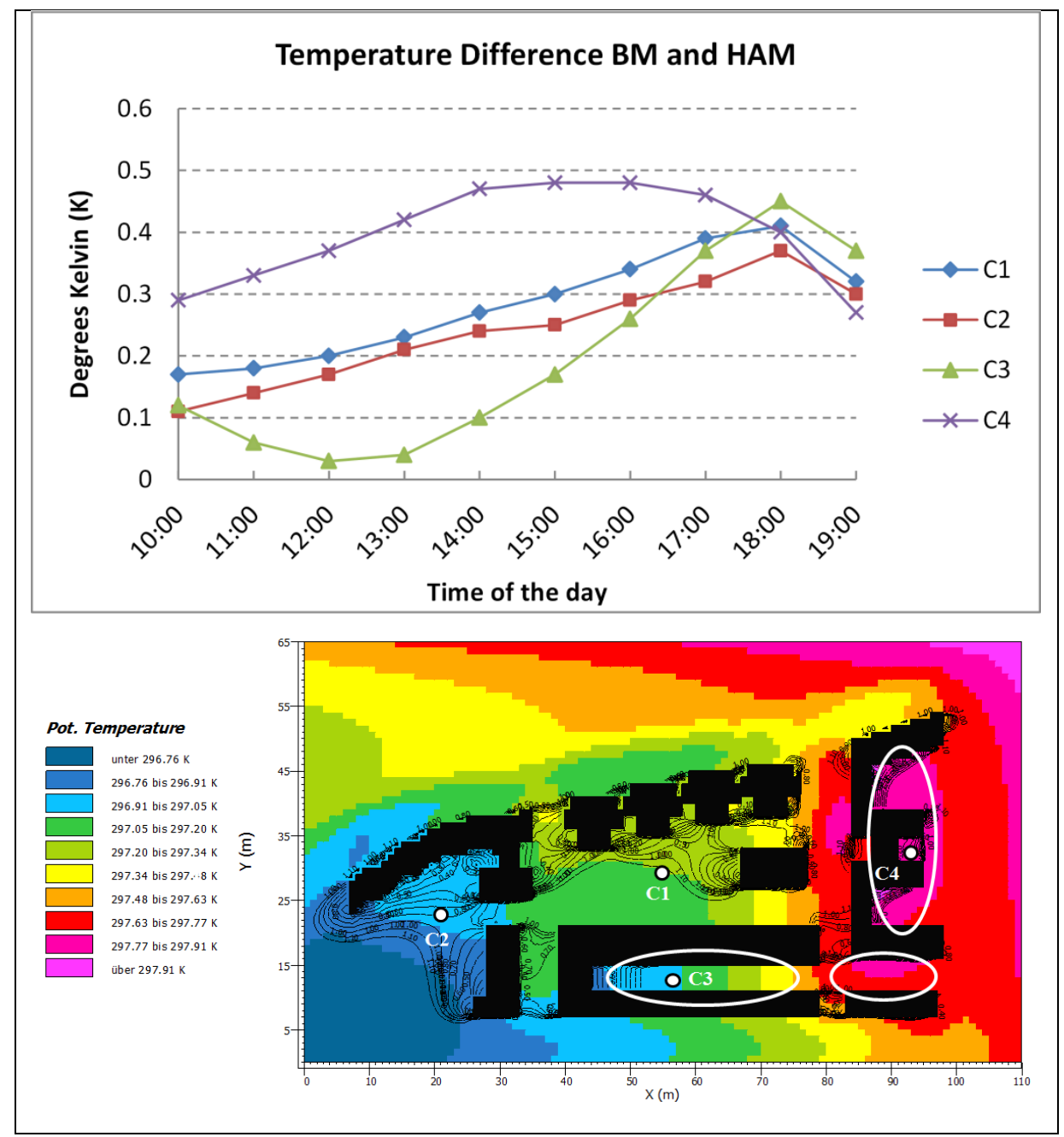

Figure 11 - High Albedo Material data: Temperature at receptors (degrees Kelvin) during the day (top) and, Heat distribution across Seagrave site (bottom)

Figure 11 (bottom) shows temperature distribution in degrees Kelvin across the site for HAM. A trend can be observed similar to all other simulation data. However in 
the receptor C4 area, the hottest part of the site, the temperature is significantly higher than other simulations. Table 1 shows the final parameters inputted into the UF assessment tool and resilient value for HAM.

\section{Discussion of Findings}

Figure 12 (top) presents ENVI-met simulation results of all UHI mitigation strategies during the day and shows that in average TSG is the most effective strategy, followed by UIWB and finally HAM. The heat reduction value of the presence of TSG is clearly present across the whole site, especially in the locations circled in the figure. A reason for this is because trees mitigate UHI effects in numerous ways: through increased shading of urban surfaces, transpiration of heat from leaves and also absorption of reflected light heat from other surfaces. This conforms to findings of previous research where street trees were shown to be beneficial particularly to 'sidewalks' (Takebayashi et al., 2014). This is especially clear within the hottest part of the site (Receptor C4: Figure 12, bottom) for 14.00-15.00 time bracket when the temperature difference to $\mathrm{HAM}$ is $1.05^{\circ} \mathrm{C}$. Additionally the contour lines of the wind have also changed with TSG (Figure 9) where they have remained similar throughout other simulations. It is likely that this has occurred because of presence of trees although it is unclear whether or not this has had a positive or negative impact on UHI intensity. This outcome aligns with and further proves previous research findings denoting that vegetation is effective for mitigating the UHI effect (Erell et al., 2011). Research also indicates that parks and green spaces help to mitigate the heat island effect and reduce energy consumption for cooling buildings in the summer, while also maintaining changes of temperature induced by building materials (Gago et al., 2013). Therefore there are multiple benefits related to inclusion of TSG within a development and this strategy is highly recommended as an UHI mitigation strategy. Vegetation scored a resilience rating of 6.25 out of 10 and is therefore a reasonable choice when aiming for resilient UHI mitigation strategy. The key issue preventing vegetation from gaining a higher rating is its vulnerability to removal as a result of land use change and issues related to maintenance. Therefore, the local councils and developers should make this a priority if resilience is to be increased. Moreover, the UFAM method identified the local context within this area of London as very strong such that it overrides planning policy and that the local council is unwilling to construct anything which does not align with it. Therefore, in terms of sustainable 
development the local context can have both a positive and negative effect. To improve validity of ENVI-met simulation results, assessment parameters inputted for TSG were adjusted to match that of the context surrounding the Seagrave car park (see Figure 3). These included trees of $5-10 \mathrm{~m}$ in height with dense crowns and dense hedges with a maximum height of $1.5 \mathrm{~m}$ to abide by local police guidelines to maintain lines of sight.

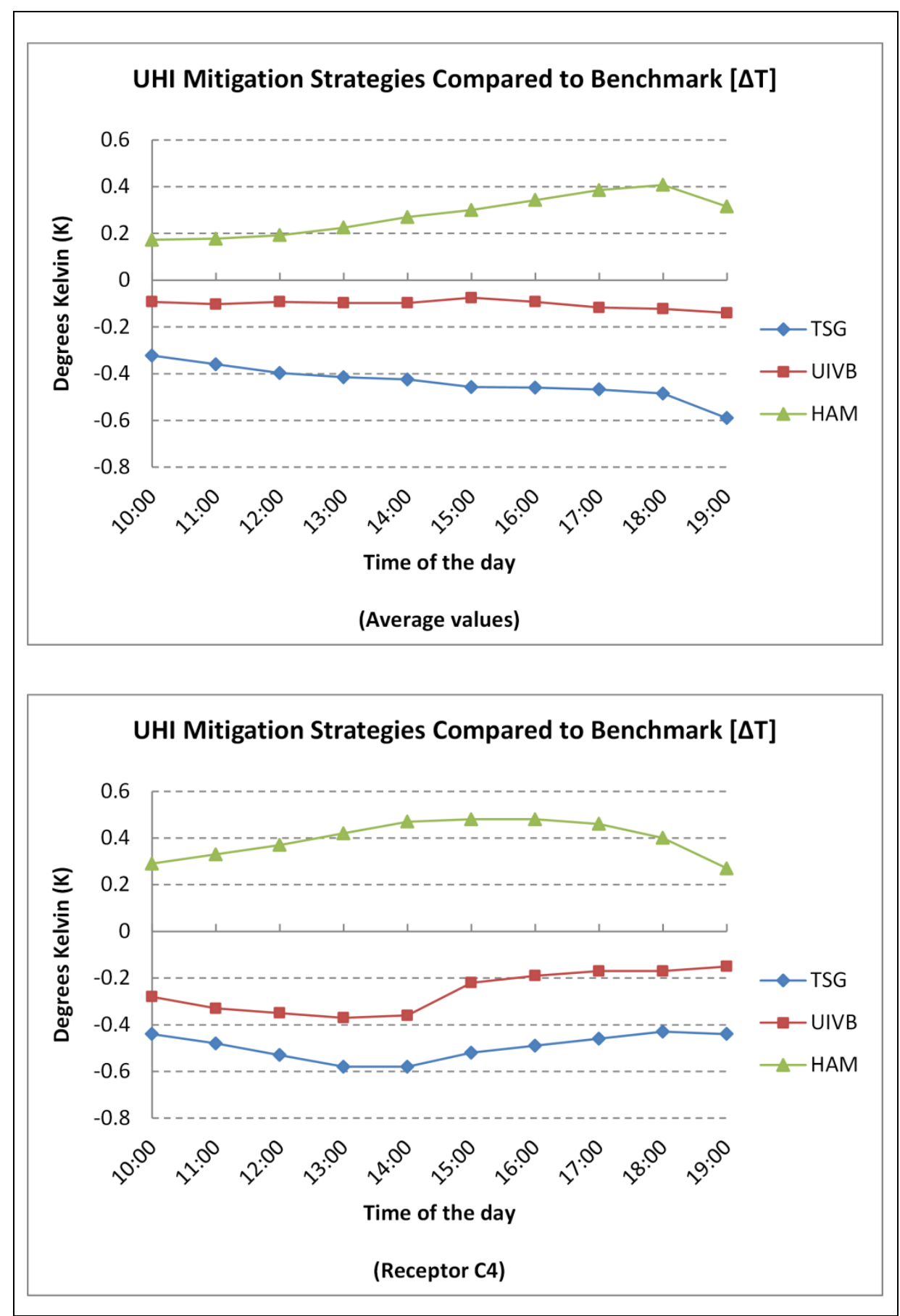

Figure 12 - All UHI mitigation strategies compared to benchmark: average temperature degrees Kelvin during the day time (top) and, temperature at receptor $\mathrm{C} 4$ during the day time in degrees Kelvin (bottom) 
With regard to ENVI-met simulations, UIWB maintains a similar atmospheric temperature to the benchmark data. The results suggest that presence of water does not mitigate the UHI which contradicts with a wealth of literature suggesting otherwise (Huang et al., 2008; Kleerekoper et al., 2012; Pitiyanuwat, 2012; Rydin et al., 2012). Although one major reason for such discrepancy can be the difference between the climate conditions of the cases studied in the literature and the selected case for this study. Nonetheless, it is still a valid argument that ENVI-met's capability to effectively measure cooling effect of UIWB has been brought into disrepute with further testing required to quantify cooling effects of water within the Seagrave development. Presence of water scored a resilience rating of 6.67 out of 10 . The key issue preventing water from gaining a higher resilience rating is also its vulnerability to removal as a result of land use change and issues related to maintenance which the local council/developers should make a priority for resilience to increase.

Use of HAM was heavily prescribed as an effective UHI mitigation strategy. However, the results of this study show that it does not have as significant an effect as suggested by previous research, especially in receptor 4's region (Figure 12). Such a discrepancy with what existing literature suggests might be due to specific layout of the site or other parameters that have not been considered in this study. The general trends available here are similar to that in other simulations as shown in Figure 12. However, the peak temperature value is higher for High Albedo data which is just over 298K compared to 297.6K for benchmark data - compared to previous research suggesting reductions of up to $8^{\circ} \mathrm{C}$ which can be linked to implications of the results being valid just for boundary conditions of the studied areas (Georgakis et al., 2014), 297K for TSG and 297.2K for UIWB. This may be because of the increased light reflection from building façade surfaces with a high albedo rating onto concrete areas between buildings and raising temperatures beyond those in other simulation data. Additionally another potential reason for this, especially at receptor 4, is the building layout which is such that allows for multiple reflections of light and heat throughout urban canyon; what is further increased by presence of HAM. The highest temperatures across all simulations are those present in the top right region of the simulation. Furthermore the layout of the buildings in the receptor 4 region reduces the amount of air movement around the buildings' contour lines (Figure 8) and this further increases temperature. It should also be noted that in the bottom centre and bottom right area of the site (Figure 11), horizontal circles, the temperatures are slightly lower on the left 
and significantly higher on the right than those in benchmark. The former area's temperature (left circle) is between $296.91 \mathrm{~K}\left(23.76^{\circ} \mathrm{C}\right)$ and $297.48 \mathrm{~K}\left(24.33^{\circ} \mathrm{C}\right)$ and the latter area's temperature (right circle) is between $297.63 \mathrm{~K}\left(24.48^{\circ} \mathrm{C}\right)$ and above $297.91 \mathrm{~K}\left(24.76^{\circ} \mathrm{C}\right)$ which is within the highest temperature bracket. The urban canyon in each area has similar dimensions. The difference in temperature combined with similar dimensions of the urban canyon suggests that if HAM are combined with the stated urban canyon dimensions and are located away from the most southerly face of the site then micro-climate temperatures will be much lower. Therefore, this demonstrates how the dimensions and locations of the urban canyon present can have both a positive and negative effect on UHI intensity depending on location.

One potential reason for ineffectiveness of HAM compared with what was found in literature can be the site layout (Erell et al., 2011) which may allow for multiple reflections of light and heat throughout urban canyons that is further amplified by the presence of HAM. These facts suggest that the use of HAM in a development can have both positive and negative effects on the microclimate between buildings and that the other factors need to be addressed for HAM to be an effective UHI mitigation strategy. Furthermore, the results show that the position and layout of the buildings are an important factor to consider when aiming at mitigating the UHI effect and that for HAM to be effective, the site layout, the building form and layout must be designed accordingly. Additional research has stated that retro-reflective materials can be used to reflect solar radiation away from the urban canyons if both urban paving and the building envelope have a high albedo rating (Rossi et al., 2014). Had the layout of buildings been designed such that natural wind could be harnessed (Rydin et al., 2012; Smith \& Levermore, 2008), this would have resulted in reduced temperatures. Moreover, research suggests that wind velocity has a significant impact on cooling and ventilation effects within a city (Vardoulakis et al., 2013). Therefore, an improved building layout determines how successful HAM will perform as a UHI mitigation strategy while also providing the opportunity to harness natural wind patterns which can further reduce UHI effect. Moreover, it has also been shown that urban grids and structures have a significant impact upon thermal behaviour of built up areas (Radhi et al., 2013). It has been stated that the distribution of buildings and urban structures within a city affect the formation and intensity of UHI since this distribution determines the absorption of solar radiation and the formation of air flows and that optimisation of urban 
design/planning in relation to energy consumption of buildings allows savings of up to $30 \%$ (Gago et al., 2013).

Additional results from ENVI-met simulations are related to distribution of surface temperatures across the site (Figure 13). The hottest surface areas of the site are in the areas of asphalt (tarmac) surfaces and these temperatures rise above $315.32 \mathrm{~K}\left(42.17^{\circ} \mathrm{C}\right)$; the hottest temperatures found anywhere on the site. This suggests that if road materials/colours are changed, they can help reduce the UHI effect. Furthermore, overheating issues related to tarmac surfaces can be further exasperated if the buildings adjacent to them have a high albedo rating and therefore there is a potential increase of sunlight being reflected onto the road, as is the case for the HAM simulation for this research project. This implies that, as previously stated, the building form must be designed properly for HAM to be an effective UHI mitigation strategy. Therefore, the replacement of tarmac with a material which does not retain heat would reduce the UHI effect in an area (Carnielo \& Zinzi, 2013). One such example is brickwork found in Lyric Square (Figure 14) in the Hammersmith and Fulham Borough. The light coloured stones have a higher albedo rating than the black tarmac surface. As identified by UFAM, the local context and influence of the area is very strong and although the brickwork does not align with that of local roads, Lyric Square is still in the same borough of London. Therefore, it is envisaged that this type of brick may be a suitable replacement for tarmac in an attempt to reduce UHI effect. However, it is important to note that Lyric Square is used as a market square and is not a residential area. This reduces the chance of it being accepted within the local context. For that reason, the local context can indirectly affect the temperature within the microclimates and how effective UHI mitigation strategies within that area can be selected and implemented. This indicates that a change in local context can indirectly be a UHI mitigation strategy but this can only occur once a change in the mindset of the local residents happened. Additionally for sustainable solutions to be implemented, such as those assessed in this research, legislations are essential. A political party is only ever in such a position to pass legislation of this type once it has been voted into office and if local governments' legislations do not align with views of the people then they will not be voted into power. This can create a self-contradictory dilemma and suggests that change needs to take place best in a bottom up approach; a change in mindset and views of people which will then enable political party to be voted in who will implement sustainable solutions by introducing 
the corresponding legislations. An additional benefit of implementation of brickwork similar to what was deployed in Lyric Square is that it would create the impression of a pedestrianized area. The benefits of pedestrianized areas include increased perception of safety due to reduced speed limits for cars; this would have an especially positive impact upon families living in the Seagrave development with children. Another would be that all people in the development would be more likely to spend time outside and interact with each other with this positively affecting the social aspect of sustainability (Erell et al., 2011).

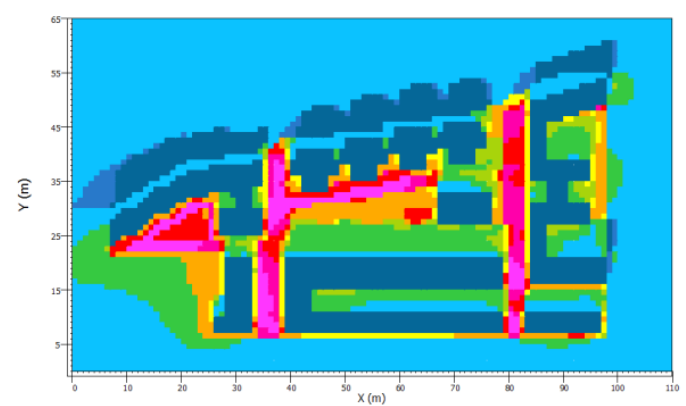

Figure 13 -ENVI-met Surface Temperature Distribution 14:00 - 15:00 (hottest hour of the day)

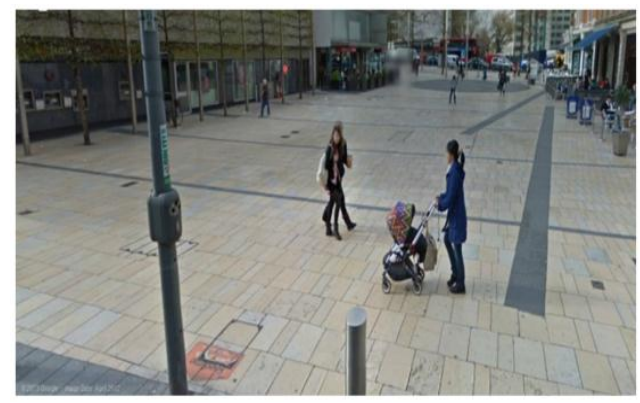

Figure 14 - Brick colour Lyric Square Hammermisth and Fulham (source: Google maps)

Considering the points raised, the completion of a final simulation was deemed necessary to allow for improved conclusions to be reached. This simulation combined TSG and HAM for the reasons suggested and also replaced asphalt road with yellow brickwork and has been labelled 'Best Case Scenario' (BCS). The BCS data collected from ENVI-met simulation produced some interesting results. As shown in Figure 15, the BCS average site temperature across the whole site throughout the day does not maintain as low a temperature as was expected.

It was expected that a combination of HAM, TSG and use of yellow bricks would produce the lowest average site temperatures in comparison with the other UHI mitigation strategies assessed. The BCS data actually showed temperatures throughout the day to be higher than BM data. This shows that the presence of TSG and yellow bricks instead of asphalt road have reduced the UHI present with just HAM. This also suggests that the presence of HAM in the building design does not actually mitigate the $\mathrm{UHI}$ and actually enhances it; this fact contradicts a wealth of literature reviewed for this study. Furthermore, this implies that either literatures reviewed are inaccurate, the ENVI-met software cannot effectively calculate reflections of light and heat throughout a simulation or that the layout of the buildings (especially around receptor (4) is such that regardless of the type of 
selected UHI mitigation strategies, they will be ineffective due to the spatial layout of the buildings.

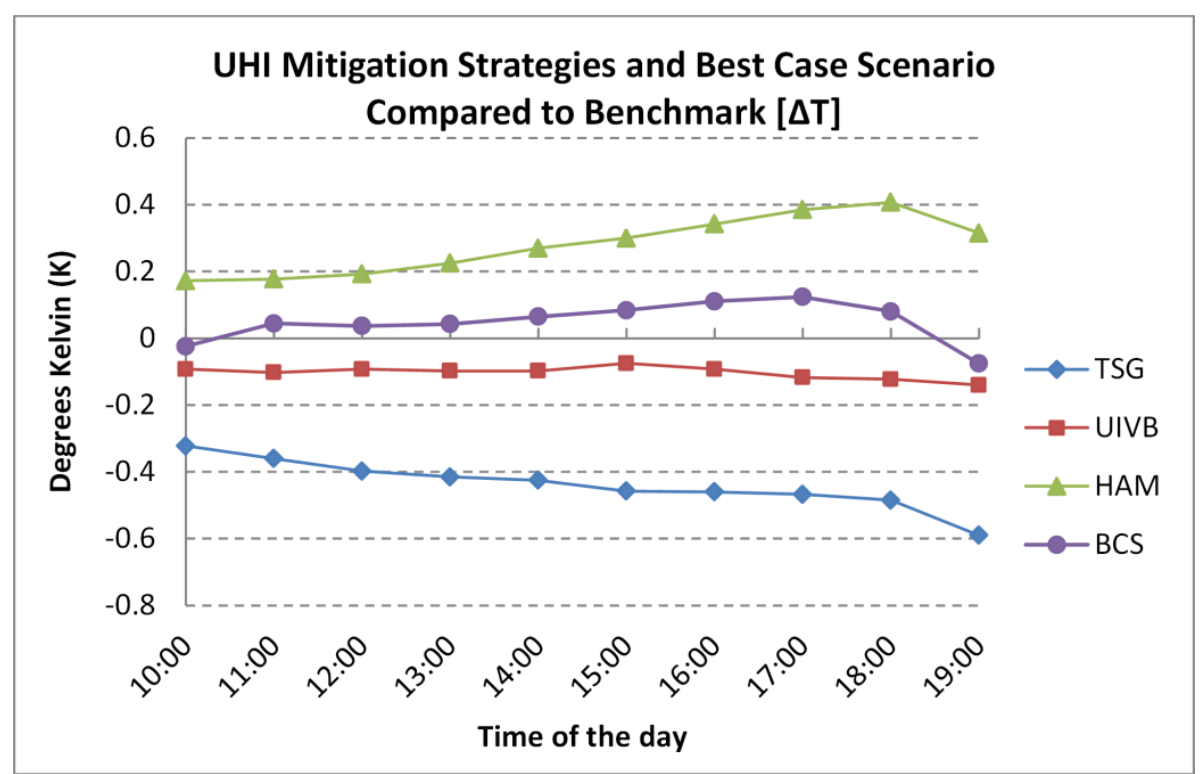

Figure 15 - Comparison of the three UHI mitigation strategies and the best case scenario (BCS) against the benchmark

\section{Conclusions}

This study suggested a systematic methodology to test the resilience of some of the most commonly used UHI mitigation strategies using a diagnostic real case study approach. The assessment was conducted using the results of an online application, ENVI-met, a prognostic three-dimensional microclimate simulation tool. It was shown how this can be applied, how the results can be presented and compared to the benchmark studies found through the literature review of this study. The interpretation of the results of this simulation was the main core of this methodology where detailed discussion of findings was presented to be used by different design professionals and local authorities. This was intended to make the best decisions in selecting $\mathrm{UHI}$ mitigating strategies and practically help the different stakeholders maximise the efficacy of the chosen strategies. Despite the broad applicability of this methodology, it will make very little sense if any at all, if proper measures are not taken to calibrate simulation parameters, and the context specifics to ensure that the most reliable simulation results are achieved. It is equally important that the results, findings and discussions are properly and proportionately contextualized in any new setting - in terms of macro-climate, micro-climate and building spatial layout - if the most 
informed decisions about the courses of action and suggestions about the most effective interventions are intended.

Throughout this study, building design, layout and form were recurring for several reasons. First of all with regards to varying temperatures of seemingly similar spots on the site which suggests there are some encompassing determinants which overrule the strategies studied in this research. Secondly as a result of effects caused by the use of HAM on building envelopes, which was resonated by some other microclimate effects that could only be attributed to the pattern of site layout. Thirdly because it was observed that the HAM effects were magnified by the surface solar radiance effects, and surface temperature of open spaces (mostly hard surfaces). And finally for the discrepancies which occurred during the new best case scenario simulation. The combination of these factors and the fact that success of other strategies is heavily dependent upon the building form and layout, suggests that the two latter are very important and effective factors and perhaps the most significant factors when UHI mitigation strategies are to be considered. This indicates that other strategies' success pivots on appropriateness and effectiveness of the chosen form and design layout. This fact aligns with and further proves that the most effective means to provide mitigation of the UHI lies within the buildings themselves. Therefore, if the UHI mitigation strategies are to be most successful, the provision of them should start early on when a new project is at conception stages where form and layout of the building can be altered and improved to ensure the effectiveness of the chosen UHI mitigation strategies. This means with assistance of simulation and analysis of UHI effects proposed within this study, the most sustainability-aware building form and site layout can be trialled and selected. This way not only the two i.e. form and layout contribute to mitigation of UHI effects but they also help the others succeed and achieve the best possible results. Suffice to say that, in an urban setting, any isolated UHI effects mitigation study of layout and massing within a specific site will be most likely prone to fail if the microclimate effects of immediate site topographies - both natural topographies, in form of land topography, greenery, water bodies, etc. and manmade topographies, including buildings, infrastructures, etc. - are underestimated or ignored. 


\section{References}

Ali-Toudert, F., \& Mayer, H. (2006). Numerical study on the effects of aspect ratio and orientation of an urban street canyon on outdoor thermal comfort in hot and dry climate. Building and Environment, 41(2), 94-108.

Alusi, A., Eccles, R. G., Edmondson, A. C., \& Zuzul, T. (2011). Sustainable cities: oxymoron or the shape of the future? Working Paper - 11-062. Boston, MA: Harvard Business School.

Borbora, J., \& Das, A. K. (2014). Summertime Urban Heat Island study for Guwahati City, India. Sustainable Cities and Society, 11(0), 61-66. doi: http://dx.doi.org/10.1016/i.scs.2013.12.001

Bruse, M. (2009). ENVI-met 3.1. Consulting and Simulation Services, Web: http://www. envimet. com.

Busato, F., Lazzarin, R. M., \& Noro, M. (2014). Three years of study of the Urban Heat Island in Padua: Experimental results. Sustainable Cities and Society, 10(0), 251-258. doi: http://dx.doi.org/10.1016/j.scs.2013.05.001

Carnielo, E., \& Zinzi, M. (2013). Optical and thermal characterisation of cool asphalts to mitigate urban temperatures and building cooling demand. Building and Environment, 60, 56-65.

Chen, Lin, T.-P., \& Matzarakis, A. (2014). Comparison of mean radiant temperature from field experiment and modelling: a case study in Freiburg, Germany. Theoretical and applied climatology, 118(3), 535-551.

Chen, H., Ooka, R., Huang, H., \& Tsuchiya, T. (2009). Study on mitigation measures for outdoor thermal environment on present urban blocks in Tokyo using coupled simulation. Building and Environment, 44(11), 2290-2299.

Chow, W. T., \& Brazel, A. J. (2012). Assessing xeriscaping as a sustainable heat island mitigation approach for a desert city. Building and Environment, 47, 170-181.

Chow, W. T., Pope, R. L., Martin, C. A., \& Brazel, A. J. (2011). Observing and modeling the nocturnal park cool island of an arid city: horizontal and vertical impacts. Theoretical and applied climatology, 103(1-2), 197-211.

Dieleman, H. (2013). Organizational learning for resilient cities, through realizing ecocultural innovations. Journal of Cleaner Production, 50, 171-180.

Dimoudi, A., Zoras, S., Kantzioura, A., Stogiannou, X., Kosmopoulos, P., \& Pallas, C. (2014). Use of cool materials and other bioclimatic interventions in outdoor places in order to mitigate the urban heat island in a medium size city in Greece. Sustainable Cities and Society, 13(0), 89-96. doi: http://dx.doi.org/10.1016/j.scs.2014.04.003

Emmanuel, R., \& Krüger, E. (2012). Urban heat island and its impact on climate change resilience in a shrinking city: The case of Glasgow, UK. Building and Environment, 53, 137-149.

Emmanuel, R., Rosenlund, H., \& Johansson, E. (2007). Urban shading-a design option for the tropics? A study in Colombo, Sri Lanka. International Journal of Climatology, 27(14), 1995-2004.

Erell, E., Pearlmutter, D., \& Williamson, T. J. (2011). Urban microclimate: designing the spaces between buildings. London - Washington, DC: Earthscan.

Fahmy, M., Hathway, A., Pattacini, L., \& Elwan, A. (2011). Environmental thermal impact assessment of regenerated urban form: A case study in Sheffield. Paper presented at the Proceedings of the World Renwable Energy Congress. 
Folke, C., Jansson, Å., Rockström, J., Olsson, P., Carpenter, S. R., Chapin III, F. S., . . Ebbesson, J. (2011). Reconnecting to the biosphere. Ambio, 40(7), 719-738.

Fujibe, F. (2011). Urban warming in Japanese cities and its relation to climate change monitoring. International Journal of Climatology, 31(2), 162-173.

Gago, E., Roldan, J., Pacheco-Torres, R., \& Ordóñez, J. (2013). The city and urban heat islands: A review of strategies to mitigate adverse effects. Renewable and Sustainable Energy Reviews, 25, 749-758.

Georgakis, C., Zoras, S., \& Santamouris, M. (2014). Studying the effect of "cool" coatings in street urban canyons and its potential as a heat island mitigation technique. Sustainable Cities and Society, 13(0), 20-31. doi: http://dx.doi.org/10.1016/i.scs.2014.04.002

Giannopoulou, K., Livada, I., Santamouris, M., Saliari, M., Assimakopoulos, M., \& Caouris, Y. G. (2011). On the characteristics of the summer urban heat island in Athens, Greece. Sustainable Cities and Society, 1(1), 16-28. doi: http://dx.doi.org/10.1016/i.scs.2010.08.003

Gobakis, K., Kolokotsa, D., Synnefa, A., Saliari, M., Giannopoulou, K., \& Santamouris, M. (2011). Development of a model for urban heat island prediction using neural network techniques. Sustainable Cities and Society, 1(2), 104-115. doi: http://dx.doi.org/10.1016/i.scs.2011.05.001

Harlan, S. L., \& Ruddell, D. M. (2011). Climate change and health in cities: impacts of heat and air pollution and potential co-benefits from mitigation and adaptation. Current Opinion in Environmental Sustainability, 3(3), 126-134.

Hathway, E., \& Sharples, S. (2012). The interaction of rivers and urban form in mitigating the Urban Heat Island effect: A UK case study. Building and Environment, 58, 14-22.

Hedquist, B. C., Brazel, A., Di Sabatino, S., Carter, W., \& Fernando, H. (2009). Phoenix urban heat island experiment: micrometeorological aspects. Paper presented at the Proceedings of the Eighth Symposium on the Urban Environment.

Hoornweg, D., Bhada, P., Freire, M., Trejos, C., \& Sugar, L. (2010). Cities and climate change: an urgent agenda. World Bank, Washington, $D C$.

Huang, L., Zhao, D., Wang, J., Zhu, J., \& Li, J. (2008). Scale impacts of land cover and vegetation corridors on urban thermal behavior in Nanjing, China. Theoretical and applied climatology, 94(3-4), 241-257.

Jabareen, Y. (2013). Planning the resilient city: Concepts and strategies for coping with climate change and environmental risk. Cities, 31, 220-229.

Jänicke, B., Meier, F., \& Hoelscher, M.-T. (2015). Evaluating the effects of façade greening on human bioclimate in a complex urban environment. Advances in Meteorology. doi: http://dx.doi.org/10.1155/2015/747259

Jansson, Å. (2013). Reaching for a sustainable, resilient urban future using the lens of ecosystem services. Ecological Economics, 86, 285-291.

Jesionek, K., \& Bruse, M. (2003). Impacts of vegetation on the microclimate: modeling standardized building structures with different greening levels. Paper presented at the Fifth Int. Conf. on Urban Climate.

Kamal-Chaoui, L., \& Roberts, A. (2009). Competitive cities and climate change OECD regional development working papers N. 2. Paris: OECD Publishing.

Kleerekoper, L., van Esch, M., \& Salcedo, T. B. (2012). How to make a city climate-proof, addressing the urban heat island effect. Resources, Conservation and Recycling, 64, 30-38. 
Kolokotroni, M., \& Giridharan, R. (2008). Urban heat island intensity in London: An investigation of the impact of physical characteristics on changes in outdoor air temperature during summer. Solar Energy, 82(11), 986-998.

Kolokotroni, M., Ren, X., Davies, M., \& Mavrogianni, A. (2012). London's urban heat island: Impact on current and future energy consumption in office buildings. Energy and Buildings, 47, 302-311.

Krüger, E., Minella, F., \& Rasia, F. (2011). Impact of urban geometry on outdoor thermal comfort and air quality from field measurements in Curitiba, Brazil. Building and Environment, 46(3), 621-634.

Lahme, E., \& Bruse, M. (2003). Microclimatic effects of a small urban park in densely built-up areas: measurements and model simulations. ICUC5, Lodz, 1-5.

Lee, D. O. (1991). Urban-rural humidity differences in London. International Journal of Climatology, 11(5), 577-582.

Lombardi, D. R., Leach, J. M., Rogers, C. D., Aston, R., Barber, A., Boyko, C., . . Caputo, S. (2012). Designing Resilient Cities: A guide to good practice. Bracknell: IHS BRE Press.

Mavrogianni, A., Davies, M., Batty, M., Belcher, S., Bohnenstengel, S., Carruthers, D., .. . Evans, S. (2011). The comfort, energy and health implications of London's urban heat island. Building Services Engineering Research and Technology, 0143624410394530.

Mihalakakou, G., Flocas, H. A., Santamouris, M., \& Helmis, C. G. (2002). Application of neural networks to the simulation of the heat island over Athens, Greece, using synoptic types as a predictor. Journal of Applied Meteorology, 41(5), 519-527.

Mikami, T. (2005). Heat island gensyo to toshigata syuchugou [The heat island phenomenon and rain storms in urban areas]. Gesuido Kyokai-shi, 42, 512-519.

Mitchell, W. J. (2009). MIT Media Lab, Spring 2009 Meeting - Smart Sustainable Cities: Wrap Up. Available at $<\underline{w w w}$.media.mit.edu/video/view/ssc-2009-04-16-9 $\rangle$. Retrieved 04/04/2013

Moonen, P., Defraeye, T., Dorer, V., Blocken, B., \& Carmeliet, J. (2012). Urban physics: effect of the micro-climate on comfort, health and energy demand. Frontiers of Architectural Research, 1(3), 197-228.

Moss, F. (2009). MIT Media Lab, Spring 2009 Meeting - Smart Sustainable Cities: Introduction. Available at <www.media.mit.edu/video/view/ssc-2009-04-16-1>. Retrieved 04/04/2013

Muller, M. (2007). Adapting to climate change water management for urban resilience. Environment and Urbanization, 19(1), 99-113.

Nakicenovic, N., \& Swart, R. (2000). Special Report on Emissions Scenarios, Edited by Nebojsa Nakicenovic and Robert Swart, pp. 612. ISBN 0521804930. Cambridge, UK: Cambridge University Press, July 2000. (Vol. 1).

$\mathrm{Ng}$, E., Chen, L., Wang, Y., \& Yuan, C. (2012). A study on the cooling effects of greening in a high-density city: An experience from Hong Kong. Building and Environment, 47(0), 256-271. doi: http://dx.doi.org/10.1016/i.buildenv.2011.07.014

Ozkeresteci, I., Crewe, K., Brazel, A., \& Bruse, M. (2003). Use and evaluation of the ENVI-met model for environmental design and planning: an experiment on linear parks. Paper presented at the Proceedings of the 21st International Cartographic Conference (ICC), Durban, South Africa.

Parker, D. E. (2004). Large-scale warming is not urban. Nature, 432(7015), 290. 
Peterson, T. C. (2003). Assessment of urban versus rural in situ surface temperatures in the contiguous United States: No difference found. Journal of Climate, 16(18), 29412959.

Pitiyanuwat, S. (2012). Report on the Urban Heat Island Effect in Hong Kong. Hong Kong: Green Power.

Rosenzweig, C., Solecki, W. D., Cox, J., Hodges, S., Parshall, L., Lynn, B., . . Savio, P. (2009). Mitigating New York City's heat island: Integrating stakeholder perspectives and scientific evaluation. Bulletin of the American Meteorological Society, 90(9), 12971312.

Roset Calzada, J., \& Vidmar, J. (2013). Evaluation of simulation tools for assessment of urban form based on physical performance.

Rydin, Y., Bleahu, A., Davies, M., Dávila, J. D., Friel, S., De Grandis, G., . . Howden-Chapman, P. (2012). Shaping cities for health: complexity and the planning of urban environments in the 21st century. Lancet, 379(9831), 2079.

Sailor, D. J., \& Fan, H. (2002). Modeling the diurnal variability of effective albedo for cities. Atmospheric Environment, 36(4), 713-725.

Santamouris, M. (2014). Cooling the cities - A review of reflective and green roof mitigation technologies to fight heat island and improve comfort in urban environments. Solar Energy, 103(0), 682-703. doi: http://dx.doi.org/10.1016/j.solener.2012.07.003

Santamouris, M., Mihalakakou, G., Papanikolaou, N., \& Asimakopoulos, D. (1999). A neural network approach for modeling the heat island phenomenon in urban areas during the summer period. Geophysical Research Letters, 26(3), 337-340.

Santamouris, M., Papanikolaou, N., Livada, I., Koronakis, I., Georgakis, C., Argiriou, A., \& Assimakopoulos, D. (2001). On the impact of urban climate on the energy consumption of buildings. Solar Energy, 70(3), 201-216.

Santamouris, M., Synnefa, A., \& Karlessi, T. (2011). Using advanced cool materials in the urban built environment to mitigate heat islands and improve thermal comfort conditions. Solar Energy, 85(12), 3085-3102.

Smith, C., \& Levermore, G. (2008). Designing urban spaces and buildings to improve sustainability and quality of life in a warmer world. Energy Policy, 36(12), 4558-4562.

Spangenberg, J., Shinzato, P., Johansson, E., \& Duarte, D. (2008). Simulation of the influence of vegetation on microclimate and thermal comfort in the city of São Paulo. Revista SBAU, Piracicaba, 3(2), 1-19.

Takebayashi, H., Kimura, Y., \& Kyogoku, S. (2014). Study on the appropriate selection of urban heat island measure technologies to urban block properties. Sustainable Cities and Society, 13(0), 217-222. doi: http://dx.doi.org/10.1016/j.scs.2014.01.008

Takebayashi, H., \& Moriyama, M. (2012). Relationships between the properties of an urban street canyon and its radiant environment: Introduction of appropriate urban heat island mitigation technologies. Solar Energy, 86(9), 2255-2262.

Tsilini, V., Papantoniou, S., Kolokotsa, D.-D., \& Maria, E.-A. (2015). Urban gardens as a solution to energy poverty and urban heat island. Sustainable Cities and Society, 14(0), 323-333. doi: http://dx.doi.org/10.1016/i.scs.2014.08.006

UN. (2010). United Nations. Department of Economic Social Affairs. Population Division World urbanization prospects: The 2009 revision: UN.

Wilby, R. L. (2003). Past and projected trends in London's urban heat island. Weather, 58(7), 251-260. 